\title{
Temporal biomass variability and production/ biomass relationships of seagrass communities
}

\author{
Carlos M. Duarte \\ Instituto de Ciencias del Mar, Paseo Nacional s/n, 08003 Barcelona, Spain
}

\begin{abstract}
Data on biomass variability and production/biomass ratios of seagrass communities were analysed to describe the relationship between the trophic (i.e. primary production) and structural (i.e. biomass) roles of marine submerged macrophytes. The analyses revealed that most $(>70 \%)$ of the biomass variability appears to reflect seasonal responses, and that the extent of variability is constrained by the latitudinal position of the plant stands, those at lower latitudes sustaining a more uniform biomass throughout the year. Annual production/biomass ratios are quite variable, although tend to be greater (average $=4.6$ ) than those for freshwater submerged plants, and tend to increase at lower latitudes. This trend is not attributable to greater daily production/biomass ratios for tropical and subtropical communities, but appears to be a consequence of their small biomass seasonality.
\end{abstract}

\section{INTRODUCTION}

Seagrass communities play 2 primary roles in coastal marine ecosystems: (1) a trophic role, through their direct contribution to ecosystem primary production (e.g. Zieman 1982, Thayer et al. 1984, Murray \& Wetzel 1987), and (2) a structural role (Kenworthy et al. 1988), because seagrass stands provide surfaces for epiphytic growth (Penhale 1977, Borum \& Wium-Andersen 1980) and shelter to animal communities (e.g. Heck \& Orth 1980, Kenworthy et al. 1988), thereby sustaining a diverse food-web (see reviews by Zieman 1982, Thayer et al. 1984, Kenworthy et al. 1988). These 2 roles are strongly coupled because the often small direct consumption of seagrass tissues (e.g. Thayer et al. 1975) results in the accumulation of primary production as seagrass biomass, which presumably determines seagrass structural importance.

The link between the trophic and the structural roles of seagrass communities can best be investigated by quantifying the relationship between biomass and primary production. Because macrophyte biomass is a cumulative property, the relationship between the biomass and annual production of seagrass communities ( $\mathrm{P} / \mathrm{B}$ ratio) has often been established on the basis of the maximum biomass attained by the community (e.g. Thorne-Miller \& Harlin 1984, Kentula \& McIntire 1986).

The structural importance of seagrass communities, however, is only partially represented by their maximum biomass because this reflects their maximum

(c) Inter-Research/Printed in F. R. Germany importance, but not the temporal variability of their structural influence (i.e. biomass variability). Quantification of biomass variability is important to any evaluation of the role of seagrass communities because this variability influences whether the export of organic carbon - to the underlying sediments or out of the seagrass meadow - is a continuous (i.e. small variability) or abrupt (i.e. high variability) process (e.g. Frankignoulle \& Bouquegnau 1987), and because biomass variability also determines the temporal variability in habitat structure experienced by seagrass-associated biota. Further, biomass variability may influence the associated biota differently depending on whether the changes are seasonal (predictable), or aseasonal (unpredictable).

Here $I$ present a first analysis of the relationship between the structural and trophic roles of seagrass communities, and of the temporal distribution of their structural influence. Because of the postulated importance of latitude in the degree of biomass variability of seagrass communities (Orth \& Moore 1986), I appraise the relationship between the different aspects of biomass variability and the latitudinal position of the plant communities. I then describe the relationship between the production and biomass of seagrass communities both on an annual and on a daily basis. To maximize the generality of the analyses I used available data on the biomass and production of a wide variety of marine angiosperm communities (Tables 1 and 2).

$0171-8630 / 89 / 0051 / 0269 / \$ 03.00$ 


\section{METHODS}

Biomass variability was characterized from the variability about the annual mean biomass of the seagrass community, quantified as the coefficient of variation and from the time of the year (i.e. month) when peak biomass was measured. The coefficient of variation of the annual biomass, which allows direct comparisons among the relative variabilities of communities differing in absolute biomass, was obtained from the available literature comprising at least bimonthly estimates of plant biomass for the periods when significant macrophyte biomass occurred. The time of maximum biomass was estimated using only literature reporting at least monthly biomass values.

To assess whether the observed biomass variability reflected seasonal or aseasonal processes I fitted a second order polynomial to the annual biomass data

$$
\text { Biomass }=a+b_{1} \text { Time }+b_{2} \text { Time }^{2}
$$

where Time is the number of months past winter solstice. Significant fits to the second order polynomial (i.e. $p<0.05$ for $t$-test on $b_{1}$ and $b_{2}$ ) indicate seasonality in plant biomass variation, whereas non-significant fits suggest aseasonal growth patterns.

The majority of the data on annual and daily macrophyte production rates were obtained with shoot or leaf marking techniques, but I also included estimates obtained with ${ }^{14} \mathrm{C}$ incorporation and $\mathrm{O}_{2}$ evolution techniques. The comparison of results from different techniques should have little impact on the analysis because differences among techniques are minor compared to the broad ranges in plant production contained in the data set (Bittaker \& Iverson 1976, Kemp et al. 1986). Nevertheless, I used analysis of covariance to test for any bias among the different techniques that could account for the patterns revealed in the analyses.

The annual balance between production and biomass was established by comparing annual production estimates with maximum aboveground biomass of the stand, and daily production-biomass balances were established by comparing daily production estimates with the aboveground biomass of the stand studied. Biomass and production estimates were transformed, when necessary, to dry weight assuming ash-free dry weight to be $80 \%$ of dry weight, and organic carbon to be $37 \%$ of dry weight (Westlake 1974). Variation around these conversion factors is expected to increase the error in the analysis, although this effect should be small because these conversions were used on less than $20 \%$ of the annual data and less than $40 \%$ of the daily data.

\section{RESULTS}

\section{Data base}

The data set included information pertaining to communities of 11 species of submerged angiosperms (Tables 1 and 2), all but 2 of them (i.e. Ruppia spp.) being marine seagrasses. A significant fraction of the literature on marine angiosperms refers to Zostera marina. The communities were located across a broad latitudinal range ( 9 to $59^{\circ}$ ), although most of the communities were temperate. Because few studies included sufficient data on biomass seasonality and annual production to be used in all analyses, the data sets used in each step of the analysis differ

\section{Biomass variability}

The extent of annual biomass variability differed greatly among macrophyte communitjes (biomass coefficient of variation ranged from 17 to $120 \%$ ), from communities with small coefficients of variation to communities experiencing very dramatic variations.

Most of the communities showed biomass variability that fitted ( $t$-test, $p<0.05$ for $b_{1}$ and $b_{2}$ in Eq. 1) a seasonal model, although the variability in a tropical $\left(9^{\circ} \mathrm{S}\right.$; Broums \& Hejs 1986) and a subtropical $\left(27^{\circ} \mathrm{S}\right.$; Boon 1986) seagrass community did not conform to the seasonal model. Seasonal changes accounted, on average, for ca $70 \%$ of the biomass variability of the communities (average $r^{2}=0.67$, maximum 0.94). The extent of variability tended to be greater for macrophyte communities in higher latitudes ( $r$ for latitudevariability $=0.43 ; p<0.05 ;$ Fig. 1 ). Closer examination of the relationship between biomass variability and latitude (Fig. 1) suggests the existence of a latitudedependent upper boundary to biomass variability rather than a tight linear relation between the 2 variables.

Most of the communities achieved their maximum biomass between July and August (January for southern hemisphere communities, Fig. 2), irrespective of their latitudinal position $(r=-0.14, p>0.05)$.

\section{Production/biomass relationships}

Peak biomass and annual production of seagrass communities ranged over an order of magnitude (Table 3), although variability in annual production was somewhat smaller (coefficient of variation $=52 \%$ ) than that in peak biomass (coefficient of variation $=70 \%$ ). The relationship between annual production (P) in $\mathrm{g}$ DW 
Table 1. Data sets used to assess the biomass variability and timing of peak biomass of seagrass communities

\begin{tabular}{|c|c|c|c|}
\hline Species & Lat. & Location & Source \\
\hline Cymodocea serrulata & $27^{\circ} \mathrm{S}$ & Australia & Boon $(1986)$ \\
\hline Cymodocea nodosa & $41^{\circ} \mathrm{N}$ & Spain & Perez \& Camp (1986) \\
\hline Enhalus acoroides & $9^{\circ} \mathrm{S}$ & Papua-N. Guinea & Brouns \& Heijs (1986) \\
\hline Halophila decipiens & $17^{\circ} \mathrm{N}$ & Virgin $\mathrm{I}$ & Williams (1988) \\
\hline Halodule wrightii & $26^{\circ} \mathrm{N}$ & USA & Morgan \& Ketting (1984) \\
\hline Heterozostera tasmanica & $38^{\circ} \mathrm{S}$ & Australia & Bulthuis \& Woelkerling (1981) \\
\hline Posidonia oceanica & $43^{\circ} \mathrm{N}$ & Spain & Romero (1985) \\
\hline Posidonia oceanica & $40^{\circ} \mathrm{N}$ & Italy & Ott $(1980$ \\
\hline Ruppia megacarpa & $35^{\circ} \mathrm{S}$ & Australia & Lukatelich et al. (1987) \\
\hline Ruppia sp. & $41^{\circ} \mathrm{N}$ & Spain & Perez \& Camp (1986) \\
\hline Syringodium filiforme & $28^{\circ} \mathrm{N}$ & USA & Gilbert \& Clark (1981) \\
\hline Thalassia testudinum & $30^{\circ} \mathrm{N}$ & USA & Iverson \& Bittaker (1986) \\
\hline Zostera capricorni & $27^{\circ} \mathrm{S}$ & Australia & Boon (1986) \\
\hline Zostera marina & $37^{\circ} \mathrm{N}$ & USA & Heck \& Orth $(1980)$ \\
\hline Zostera marina & $37^{\circ} \mathrm{N}$ & USA & Heck \& Thoman (1984) \\
\hline Zostera marina & $44^{\circ} \mathrm{N}$ & USA & Kentula \& McIntire (1986) \\
\hline Zostera marina & $37^{\circ} \mathrm{N}$ & USA & Orth \& Moore (1986) \\
\hline Zostera manina & $53^{\circ} \mathrm{N}$ & England & Wyer et al. (1977) \\
\hline Zostera marina & $56^{\circ} \mathrm{N}$ & Denmark & Sand-Jensen (1975) \\
\hline Zostera marina & $52^{\circ} \mathrm{N}$ & Netherlands & Nienhuis \& DeBree $(1980)$ \\
\hline Zostera marina & $56^{\circ} \mathrm{N}$ & Denmark & Wium-Andersen \& Borum (1984) \\
\hline Zostera marina & $37^{\circ} \mathrm{N}$ & USA & Adams $(1976)$ \\
\hline Zostera marina & $37^{\circ} \mathrm{N}$ & USA & Penhale (1977) \\
\hline Zostera marina & $52^{\circ} \mathrm{N}$ & Netherlands & Nienhuis \& Caperon (1986) \\
\hline Zostera marina & $44^{\circ} \mathrm{N}$ & Canada & Robertson \& Mann (1984) \\
\hline Zostera noltii & $41^{\circ} \mathrm{N}$ & Spain & Perez \& Camp (1986) \\
\hline
\end{tabular}

Table 2. Data sets used to assess daily [P/B (d)], and annual [P/B, (yr)] production/biomass balances of seagrass communities

\begin{tabular}{|c|c|c|c|c|c|}
\hline Species & Lat. & Location & $\mathrm{P} / \mathrm{B}(\mathrm{yr})$ & $P / B(d)$ & Source \\
\hline Zostera marina & $40^{\circ} \mathrm{N}$ & USA & & $x$ & Dennison \& Alberte (1985) \\
\hline Zostera marina & $40^{\circ} \mathrm{N}$ & USA & & $\mathrm{x}$ & Dennison \& Alberte (1986) \\
\hline Posidonia oceanica & $35^{\circ} \mathrm{N}$ & Italy & & $x$ & Drew (1978) \\
\hline Zostera marina & $44^{\circ} \mathrm{N}$ & USA & $x$ & $x$ & Kentula \& McIntire (1986) \\
\hline Zostera marina & $41^{\circ} \mathrm{N}$ & USA & & $\mathrm{x}$ & Thorne-Miller \& Harlin (1984) \\
\hline Enhalus acoroides & $9^{\circ} \mathrm{S}$ & Papua N. Guinea & $x$ & $\mathrm{X}$ & Brouns \& Heijs (1986) \\
\hline Thalassia hemprichii & $9^{\circ} \mathrm{S}$ & Papua N. Guinea & $x$ & $\mathrm{x}$ & Brouns \& Heijs (1986) \\
\hline Posidonia oceanica & $43^{\circ} \mathrm{N}$ & Spain & $\mathrm{x}$ & $\mathrm{x}$ & Romero (1985) \\
\hline Posidonia oceanica & $35^{\circ} \mathrm{N}$ & Italy & & $\mathrm{x}$ & Velimirov (1986) \\
\hline Zostera marina & $44^{\circ} \mathrm{N}$ & Canada & $\mathrm{x}$ & $\mathrm{x}$ & Robertson \& Mann (1984) \\
\hline Posidonia australis & $32^{\circ} \mathrm{S}$ & Australia & $\mathrm{x}$ & $\mathrm{X}$ & Silberstein et al. (1986) \\
\hline Halophila decipiens & $17^{\circ} \mathrm{N}$ & Virgin I. & & $\mathrm{x}$ & Josselyn \& Fonseca (1986) \\
\hline Posidonia oceanica & $42^{\circ} \mathrm{N}$ & France & $x$ & & Bay (1984) \\
\hline Thalassia hemprichii & $9^{\circ} \mathrm{S}$ & Papua N. Guinea & & $\mathrm{x}$ & Brouns $(1985)$ \\
\hline Thalassia testudinum & $23^{\circ} \mathrm{N}$ & Cuba & $\mathrm{x}$ & $\mathrm{x}$ & Buesa (1974) \\
\hline Zostera marina & $52^{\circ} \mathrm{N}$ & Netherlands & $\mathrm{x}$ & $\mathrm{X}$ & Nienhuis \& DeBree (1980) \\
\hline Zostera marina & $37^{\circ} \mathrm{N}$ & USA & $\mathrm{X}$ & $\mathrm{x}$ & Penhale (1977) \\
\hline Posidonia oceanica & $37^{\circ} \mathrm{N}$ & Italy & $\mathrm{x}$ & $x$ & Ott $(1980)$ \\
\hline Zostera marina & $56^{\circ} \mathrm{N}$ & Denmark & $\mathrm{x}$ & $\mathrm{X}$ & Sand-Jensen (1975) \\
\hline Zostera marina & $56^{\circ} \mathrm{N}$ & Denmark & $\mathrm{x}$ & $x$ & Wium-Andersen \& Borum (1984) \\
\hline Halodule wrightii & $26^{\circ} \mathrm{N}$ & USA & $\mathrm{x}$ & $\mathrm{x}$ & Morgan \& Ketting (1984) \\
\hline Thalassia testudinum & $27^{\circ} \mathrm{N}$ & USA & & $\mathrm{x}$ & Dawes \& Tomasko (1988) \\
\hline Thalassia testudinum & $13^{\circ} \mathrm{N}$ & Barbados & & $\mathrm{x}$ & Patriquin (1973) \\
\hline Syringodium filiforme & $27^{\circ} \mathrm{N}$ & USA & & $\mathrm{x}$ & Fry \& Virnstein (1988) \\
\hline Thalassia testudinum & $25^{\circ} \mathrm{N}$ & USA & & $\mathrm{X}$ & Capone et al. (1979) \\
\hline
\end{tabular}


$\mathrm{m}^{-2} \mathrm{yr}^{-1}$ and maximum macrophyte biomass $(B)$ in $\mathrm{g}$ DW $\mathrm{m}^{-2}$ was best described by the relation

$$
\begin{gathered}
\log \mathrm{P}=1.6+0.32 \log \mathrm{B} \\
r^{2}=0.24, p<0.05, \mathrm{SE} \log \text { estimate }=0.20
\end{gathered}
$$

The relation between annual biomass and production is relatively weak (Fig, 3) reflecting variability in $\mathrm{P} / \mathrm{B}$ ratios for different macrophyte communities (Fig. 4). Among the possible sources of variation in the $\mathrm{P} / \mathrm{B}$ ratios of macrophyte communities I was able to test the importance of (1) differences among methods, and (2)

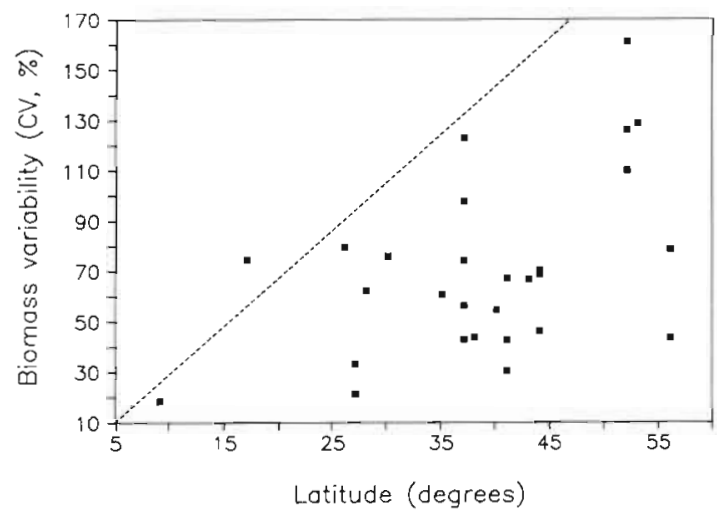

Fig. 1 Relation between degree of biomass variability (as coefficient of variation of mean annual biomass), and latitudinal position of stands. Broken line represents the suggested latitudinal-dependent boundary to biomass seasonality

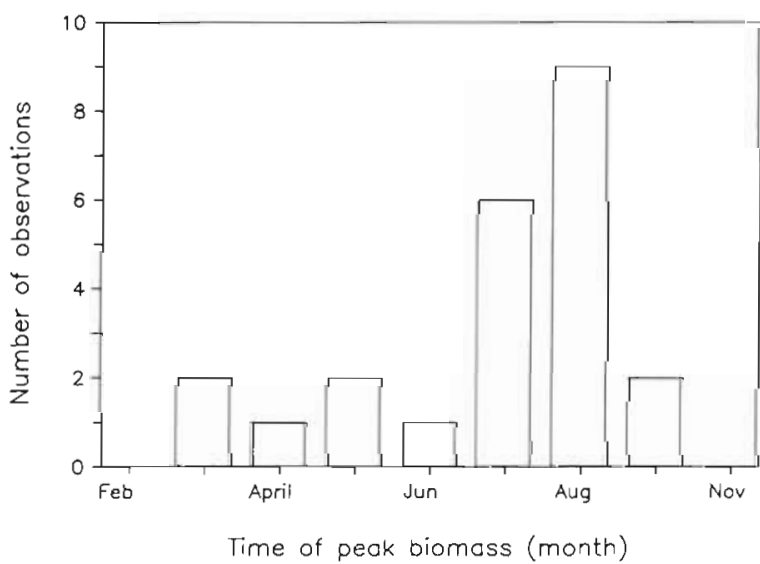

Fig. 2. Frequency distribution of the month when peak seagrass biomass occurs. June corresponds to December for southern hemisphere communities

Table 3. Mean and range for the daily and annual production rates and the maximum biomass $\left(\mathrm{B}_{\max }\right)$ of the stands in the data set (Tables 1 and 2)

\begin{tabular}{|lcc|}
\hline Variable & Mean & Range \\
\hline $\mathrm{B}_{\max }\left(\mathrm{g} \mathrm{DW} \mathrm{m}^{-2}\right.$ ) & 315 & $50-854$ \\
Production $\left(\mathrm{g} \mathrm{DW} \mathrm{m} \mathrm{m}^{-2} \mathrm{~d}^{-1}\right)$ & 3.6 & $0.1-28.5$ \\
Production $\left(\mathrm{g} \mathrm{DW} \mathrm{m} \mathrm{ys}^{-1}\right)$ & 973 & $239-2557$ \\
\hline
\end{tabular}

differences in the latitudinal position of the communities. The importance of differences in production methods was tested using analysis of covariance on the relation between annual production and maximum biomass. This analysis showed no evidence of any effect of differences in methods ( $F$-test, $p>0.05$ ) on the relation

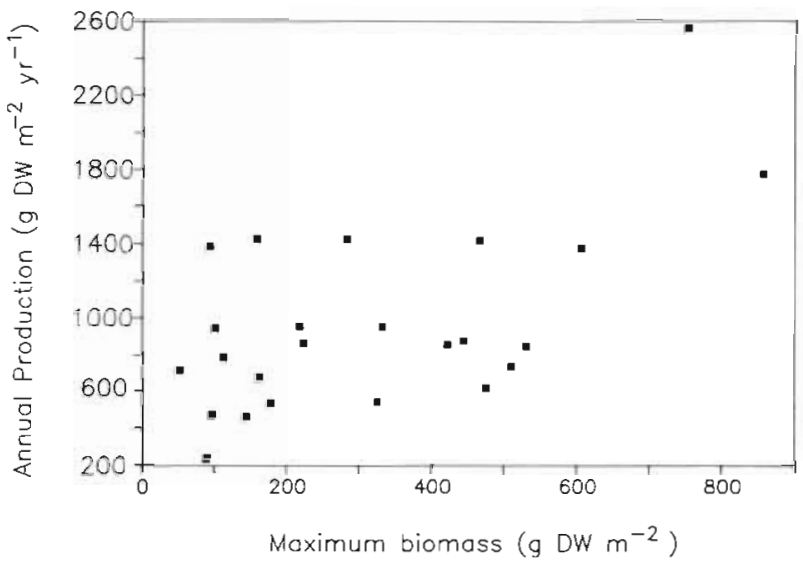

Fig. 3. Relationship between maximum biomass and annual production of seagrass communities

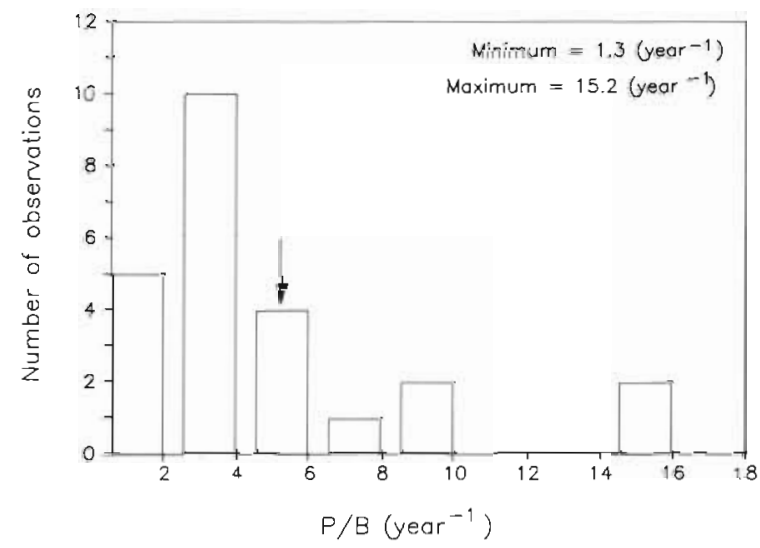

Fig. 4. Frequency distribution of the annual production/biomass ratios of seagrass communities. Arrow indicates average ratio

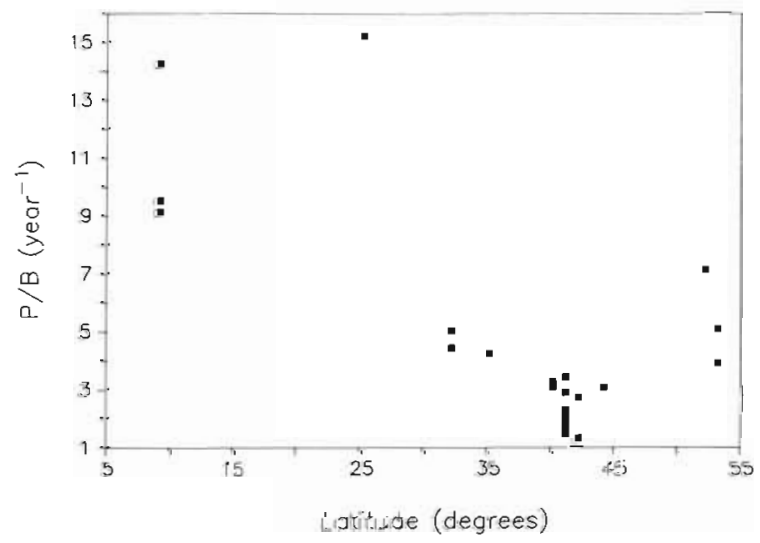

Fig. 5. Relationship between annual production/biomass ratio and latitudinal position of communities 


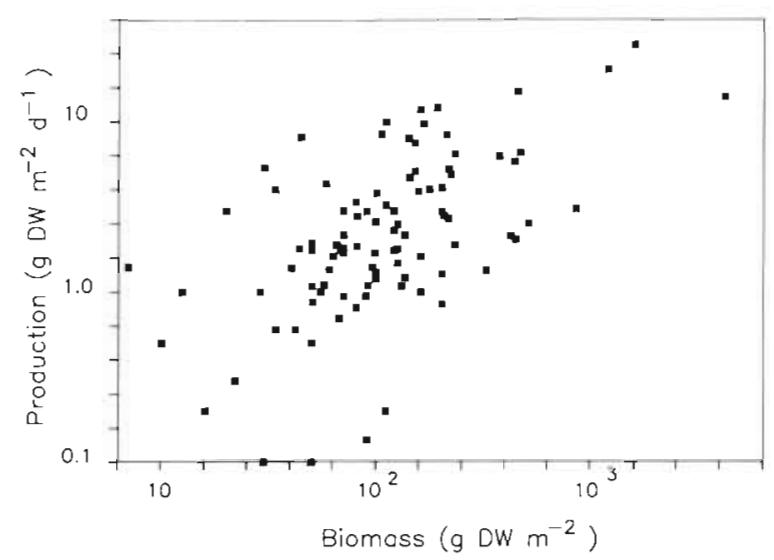

Fig. 6. Relationship between daily production rates and aboveground seagrass biomass

between production and biomass. The $\mathrm{P} / \mathrm{B}$ ratio of the seagrass communities decreased significantly with increasing latitude $(r=-0.70, p<0.01$; Fig. 5). This result, however, should be regarded as only indicative until further data on $\mathrm{P} / \mathrm{B}$ ratios for tropical and subtropical stands become available. The weak relation between annual production and peak biomass was partially a result of the confounding influence of differences in latitude (partial correlation between annual production and peak biomass $=0.61, p<0.01$, with latitude held constant).

The relation between daily production $\left(\mathrm{P}_{\mathrm{d}}\right)$ in $\mathrm{g} D \mathrm{DW}$ $\mathrm{m}^{-2} \mathrm{~d}^{-1}$ and biomass $\left(\mathrm{B}_{\mathrm{d}}\right)$ in $\mathrm{g} \mathrm{DW} \mathrm{m}^{-2}$ (Fig. 6) was described by the equation

$$
\begin{gathered}
\log \mathrm{P}_{\mathrm{d}}=0.60 \log \mathrm{B}_{\mathrm{d}}-0.89 \\
r^{2}=0.51, p<0.0001, \mathrm{SE} \log \text { estimate }=0.40
\end{gathered}
$$

The imprecision of daily production rates estimated from areal biomass (regression error ca 2.5-fold) reflects the variability of daily $\mathrm{P} / \mathrm{B}$ ratios (Fig. 7). The variability in daily biomass turnover times (5 to $666 \mathrm{~d}$ ) appears to be unrelated to latitude $(r=0.10, p>0.05)$, or to the methods used to quantify daily production (ANCOVA, $F$-test, $p>0.05$ ). The overall variability in daily $\mathrm{P} / \mathrm{B}$ was quite large (coefficient of variation = $119 \%$, and was partially related to temporal $P / B$ variability (i.e. within a stand, range of within-stand coefficient of variation 28 to $116 \%$, average $62.6 \%, n=6$ ).

\section{DISCUSSION}

\section{Biomass seasonality}

Seasonality explained a substantial fraction (average $67 \%$ ) of the biomass variability of the seagrass communities examined. This is a conservative estimate because the simple model used to assess seasonality

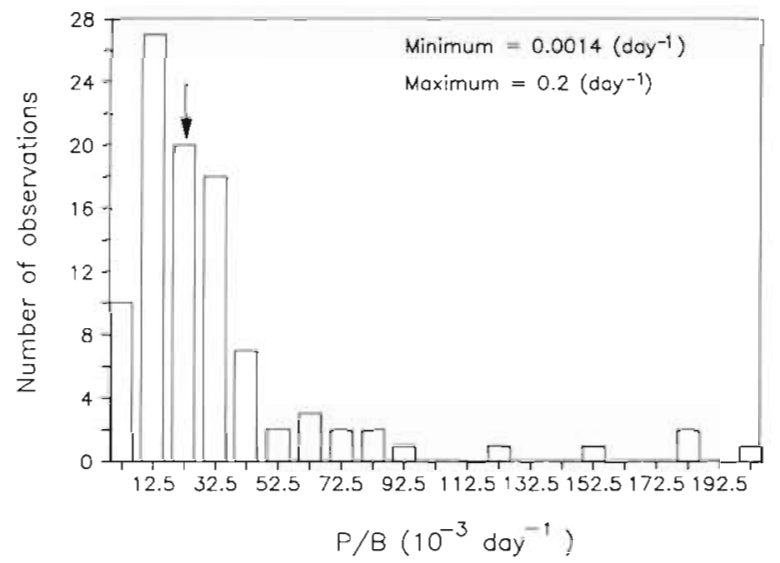

Fig. 7. Frequency distribution of the daily production/biomass ratios of seagrass communities. Arrow indicates average ratio

(Eq. 1) may not be equally appropriate to all seasonal responses. The importance of seasonality, however, does not imply that it is the sole source of biomass variability, since other factors (e.g. disturbance) combine with seasonal responses to yield the observed biomass variability. The extent of biomass seasonality appears to be constrained, but not determined, by the latitudinal position of the seagrass communities (Fig. 1). Thus, temperate communities often show greater seasonality than tropical and subtropical ones, but temperate communities also appear capable of displaying a wider range of seasonal responses (Fig. 1). For instance, annual and perennial forms of Zostera marina are known to coexist in the same coastal zones (e.g. Keddy \& Patriquin 1978), and depth-related differences in the exposure to disturbance or stress often result in different seasonal responses within the same location (e.g. Robertson \& Mann 1980, Williams 1988).

Patterns of biomass seasonality in seagrass communities qualitatively resemble patterns for many terrestrial plants (e.g. Lieth 1974). The seasonality of terrestrial plants also shows clear latitudinal trends (Lieth 1974), and displays a wide range of variability within latitudes (Lechowicz 1984). Similarly, the sources of variability in the seasonal response of seagrass communities growing at the same latitude may be analogous to those in terrestrial plant stands: (1) climatic (e.g. degree-days) and environmental (e.g. disturbance) differences among locations and among years (e.g. Taylor 1974, Robertson \& Mann 1980, Orth \& Moore 1986, Williams 1988), and (2) genetic differences among species (i.e. growth strategies; e.g. Williams 1987).

The latitude-constrained degree of seasonality in biomass has important ecosystem implications. The more constant seagrass biomass at low latitudes implies that benthic communities associated with macrophyte beds should receive a relatively constant sup- 
ply of macrophyte-derived organic carbon. Similarly, the availability of substrate for epiphytic growth throughout the year must increase ecosystem primary and secondary production, and significantly influence the chemical and trophic balances of the ecosystem. On the other hand, the greater biomass variability of temperate seagrass communities indicate that their associated biota should experience considerable habitat change throughout the year.

The period of maximum biomass is rather predictable for most communities, and generally occurs (in the northern hemisphere) sometime between July and August (Fig. 2). The lack of relationship between the time when maximum biomass is reached and latitude has at least 3 possible explanations: (1) it may be that the timing of these events is determined by the occurrence of peak irradiance (Sand-Jensen 1975), which is roughly similar for all latitudes; $(2)$ it is possible that the resolution of our analysis (month) is insufficient to detect the influence of latitude on the timing of peak biomass; and (3) it may be that sufficient variability in the timing of maximum biomass is due to differences in environmental conditions to obscure any relationship to latitude. Unfortunately, detailed data are too scarce to adequately evaluate the merits of these complementary explanations, although existing evidence suggests that both genetic and environmental control are responsible for the seasonal biomass pattern (Pirc 1986, Williams 1988).

\section{Biomass-production relationships}

Results indicate that maximum seagrass biomass is only weakly related to annual production (Eq. 1; Fig. 3). This results from the very wide variability in seagrass P/B (Fig. 5) compared to those of freshwater macrophytes (range 0.7 to 2.6, from Westlake 1982). Further, seagrass communities tend to have greater annual $P / B$ than those reported for freshwater angiosperms (Westlake 1982). I believe that both the greater and more variable $\mathrm{P} / \mathrm{B}$ ratios of seagrass communities compared to freshwater macrophytes result from growth form differences between plants inhabiting the two systems (Duarte unpubl.). Marine angiosperms cope with epiphytic accretion by sloughing off leaves after 10 to 30 wk (e.g. Ott 1980, Wahbeh 1984), thereby decreasing aboveground biomass, whereas peak biomass of freshwater angiosperms reflects better the aboveground material produced (Stevenson 1988).

Daily $P / B$ shows considerable variation within stands and within species. The reason for this may be that daily $\mathrm{P} / \mathrm{B}$ is closely dependent on the particular light conditions experienced by the stand (e.g. Kemp et al. 1987), and day-to-day variability in irradiance is likely to be much greater than that in annual irradiance. Since tropical seagrass communities did not show greater daily $\mathrm{P} / \mathrm{B}$ than those at higher latitudes, the greater annual $\mathrm{P} / \mathrm{B}$ of communities inhabiting tropical and subtropical latitudes (Fig. 5) should be a consequence of their smaller biomass seasonality,

In summary, the analyses show that tropical and subtropical communities should provide a more stable habitat for associated biota than communities at higher latitudes, and at the same time should provide more organic carbon for a given structural role (i.e. greater annual $\mathrm{P} / \mathrm{B}$ ). The important ecosystem implications of these patterns of biomass seasonality and their influence on the balance between production and biomass enhance the need for greater research efforts directed to quantify the contributions of species-specific adaptations and environmental conditions to the seasonality of seagrasses.

Acknowledgements. I thank 2 anonymous reviewers for their criticisms that helped to improve the paper.

\section{LITERATURE CITED}

Adams, S. M. (1976). The ecology of eelgrass Zostera marina (L.) fish communities. I. Structural analysis. J. exp. mar. Biol. Ecol. 22: 269-291

Bay, D. (1984). A field study of the growth dynamics and productivity of Posidonia oceanica (L.) Delile in Calvi Bay, Corsica. Aquat. Bot. 20: 43-64

Bittaker, H. F., Iverson, R. L. (1976). Thalassia testudinum productivity: a field comparison of measurement methods. Mar. Biol. 37: 39-46

Boon, P. I. (1986). Nitrogen pools in seagrass beds of Cymodocea serrulata and Zostera capricorni of Moreton Bay, Australia. Aquat. Bot. 25: 1-9

Borum, J., Wium-Andersen, S. (1980). Biomass and production of epiphytes on eelgrass (Zostera marina L.) in the Oresund, Denmark. Ophelia 1 (Suppl.): 57-64

Brouns, J. J. W. M. (1985). A comparison of the annual production and biomass in three nonspecific stands of the seagrass Thalassia hemprichii (Ehremb.) Aschers. Aquat. Bot. 23: $149-175$

Brouns, J. J. W. M., Heijs, F. M. L. (1986). Production and biomass of the seagrass Enhalus acoroides (L. t.) Royle and its epiphytes. Aquat. Bot. 25: 21-45

Buesa, R. J. (1974). Population and biological data on turtlegrass (Thalassia testudinum) Konig 1805 on the Northwestern Cuban shelf. Aquaculture 4: 207-226

Bulthuis, D. A., Woelkerling, Wm. J. (1981). Effects of in situ nitrogen and phosphorus enrichment of the sediments on the seagrass Heterozostera tasmanica (Martens, ex Aschers) den Hartog in Western Port, Victoria, Australia. J. exp. mar Biol. Ecol. 53: 193-207

Capone, D. G., Penhale, P. A., Oremland. S., Taylor, B. F. (1979). Relationship between productivity and $\mathrm{N}:\left(\mathrm{C}_{2} \mathrm{H}_{2}\right)$ fixation in a Thalassia testudinum communıty. Lımnol. Oceanogr 24: 117-125

Dawes, C. J., Tomasko, D. A. (1988). Depth distribution of Thalassia testudinum in two meadows on the West coast of 
Florida; a difference in the effect of light availability. P. S. Z. N. I. Mar. Ecol. 9: 123-130

Dennison, W. C., Alberte, R. S. (1985). Role of daily light period in the depth distribution of Zostera marina (eelgrass). Mar Ecol. Prog. Ser 25: 51-61

Dennison, W C., Alberte, R. S. (1986). Photoadaptation and growth of Zostera marina L. (eelgrass) transplants along a depth gradient. J. exp. mar Biol. Ecol. 98: 265-282

Drew, E. A (1978). Factors affecting photosynthesis and its seasonal variation in the seagrass Cymodocea nodosa (Ucria) Aschers, and Posidonia oceanica (L.) Delile in the Mediterranean. J. exp. mar. Biol. Ecol. 31 173-194

Frankignoulle, M., Bouquegneau, J. M. (1987). Seasonal variation in the diel carbon budget of a marine macrophyte ecosystem. Mar. Ecol. Prog. Ser. 38: 197-199

Fry, B., Virnstein, R. W. (1988). Leaf production and export of the seagrass Syringodium filiforme Kutz in Indian River Lagoon, Florida. Aquat. Bot. 30: 261-266

Gilbert, S., Clark, K. B. (1981). Seasonal variation in standing crop of the seagrass Syringodium filiforme and associated macrophytes in the Northern Indian River, Florida. Estuaries 4: 223-225

Heck, K. L., Orth, R. J. (1980). Structural components of the eelgrass (Zostera marina) meadows in the lower Chesapeake Bay - decapod crustaceans. Estuaries 3: 289-295

Heck, K. L., Thoman, T A. (1984). The nursery role of seagrass meadows in the upper and lower reaches of the Chesapeake Bay. Estuaries 7. 70-92

Iverson, R. L., Bittaker, H. F. (1986). Seagrass distribution and abundance in Eastern Gulf of Mexico coastal waters Estuar. coast. Shelf Sci. 22: 577-602

Josselyn, M. Fonseca, M. (1986). Biomass, production, and decomposition of a deep water seagrass, Halophila decipiens Ostenf. Aquat. Bot. 25: 47-61

Keddy, J., Patriquin, D. G. (1978). An annual form of eelgrass in Nova Scotia. Aquat. Bot. 5: 163-170

Kemp, W. M., Lewis, M. R., Jones, T W. (1986). Comparison of methods for measuring production by the submersed macrophyte, Potamogeton perfoliatus L. Limnol. Oceanogr. 31 $1322-1334$

Kemp, W. M., Murray, L., Borum, J., Sand-Jensen, K. (1987) Diel growth in eelgrass Zostera marina. Mar Ecol. Prog Ser. 41 79-86

Kentula, M. E., McIntire, C. D. (1986). The autoecology and production dynamics of eelgrass (Zostera marina L.) in Netarts Bay, Oregon. Estuaries 9: 188-199

Kenworthy, W. J., Thayer, G. W., Fonseca, M. S. (1988). The utilization of seagrass meadows by fishery organisms. In Hook, D. D., McKee, W. H. Jr, Smith, H. K., Gregory, J. Burrell, V G. Jr, DeVoe, M. R., Sojka, R. E., Gilbert, S. Banks, R., Stolzy, L. H., Brooks, C., Matthews, T D., Shear, $\mathrm{T}$ H., (eds.) The ecology and management of wetlands Vol. I. Timber Press, Oregon, p. 548-560

Lechowicz, M. J. (1984). Why do temperate deciduous trees leaf out at different times? Adaptation and ecology of forest communities. Am. Nat. 124: 821-842

Lieth, H. (1974). Phenology and seasonality modelling. Springer-Verlag, New-York

Lukatelich, N., Schofield, J., McComb, A. J. (1987). Nutrient loading and macrophyte growth in Wilson inlet, a bar-built southwestern Australian estuary. Estuar. coast. Shelf Sci. 24: $141-165$

Morgan, M. D., Ketting, C. L. (1984). Productivity and utilization of the seagrass Halodule wrightii and its attached epiphytes. Limnol. Oceanogr. 29: 1066-1076

Murray, L., Wetzel, R. L. (1987). Oxygen production and consumption associated with the major autotrophic components in two temperate seagrass communities. Mar. Ecol. Prog. Ser 38: 231-239

Nienhuis, P. H., DeBree, B. H. H. (1980). Production and growth dynamics of eelgrass (Zostera marina) in brackish Lake Greevelingen (The Netherlands). Neth. J. Sea Res. 14: $102-118$

Nienhuis, P. H., Caperon, J. (1986). Consumption of eelgrass (Zostera marina) by birds and invertebrates: an annual budget. Mar Ecol. Progr Ser 29: 29-35

Ott, J. A. (1980). Growth and production in Posidonia oceanica (L.) Delile. P. S. Z. N. I. Mar. Ecol. 1: 47--64

Orth, R. J., Moore, K. A. (1986). Seasonal and year-to-year variations in the growth of Zostera marina L. (eelgrass) in the lower Chesapeake Bay. Aquat. Bot. 24: 335-341

Patriquin, D. (1973). Estimation of growth rate, production, and age of the marine angiosperm Thalassia testudinum König. Caribb. J. Sci 13: 111-123

Penhale, P. A. (1977). Macrophyte-epiphyte biomass and productivity in an eelgrass (Zostera marina L.) community. J exp. mar. Biol. Ecol. 26: 211-224

Perez, M., Camp, J. (1986). Distribution espacial y biomasa de las fanerogamas marinas de las bahias del Delta del Ebro. Investigación Pesq. 50: 519-530

Pirc, H. (1986). Seasonal aspects of photosynthesis in Posidonia oceanica: Influence of depth, temperature and light intensity. Aquat. Bot. 26: 203-212

Robertson, A. I., Mann, K. H. (1984). Disturbance by ice and life-history adaptations of the seagrass Zostera marina. Mar Biol. 80: 131-141

Romero, J. (1985). Estudio ecologico de las fanerogamas marinas de la costa catalana: producción primaria de Posidonia oceanica (L.) Delile en las islas Medes. Ph. D. Thesis, University of Barcelona

Sand-Jensen, K. (1975). Biomass, net production and growth dynamics in an eelgrass (Zostera marina L.) population in Vellerup Vig, Denmark. Ophelia 14: 185-201

Silberstein, K., Chiffings, A. W., McComb, A. J. (1986). The loss of seagrass in Cockburn Sound, Western Australia. III The effect of epiphytes on productivity of Posidonia australis Hook F. Aquat. Bot. 24: 355-371

Stevenson, J. C. (1988). Comparative ecology of submersed grass beds in freshwater, estuarine, and marine environments. Limnol Oceanogr. 33: 867-893

Taylor, F. G., Jr (1974). Phenodynamics of production in a mesic deciduous forest. In: Lieth, H. (ed.) Phenology and seasonality modelling. Springer-Verlag, New York, p. $237-254$

Thayer, G. W., Adams, S. M., La Croix, M. W. (1975) Structural and functional aspects of a recently established Zostera marina community. In: Cronin, L. E. (ed.) Estuarine research, Vol. 1. Academic Press, New York, p. $518-546$

Thayer, G. W., Kenworthy, W J., Fonseca F. S. (1984). The ecology of eelgrass meadows of the Atlantic coast: a community profile. U. S. Fish Wildl. Serv. FWS/OBS-84/02, 147 pp.

Thorne-Miller, B., Harlin, M. M. (1984). The production of Zostera marina L. and other submerged macrophytes in a coastal lagoon in Rhode Island, USA. Botanica mar. 27: 539-545

Velimirov, B. (1986). DOC dynamics in a Mediterranean seagrass system. Mar. Ecol. Prog. Ser. 28: 21-41

Wahbeh, M. I. (1984). The growth and production of the leaves of the seagrass Halophila stipulacea (Forsk.) Aschers. from Aqaba, Jordan. Aquat. Bot. 20: 33-41

Westlake, D. F. (1974). Sampling techniques and methods for 
estimating quantity and quality of biomass (macrophytes). In: Vollenweider, R. A. (ed.) A manual of methods for measuring primary production in aquatic environments. I. B. P. Handb. 12. Blackwell, Oxford, p. 32-41

Westlake, D. F. (1982). The primary productivity of water plants. In: Symoens, J. J., Hooper, S. S., Compere, P. (eds.) Studies on aquatic vascular plants. Royal Botanical Society of Belgium, Brussels, p. 165-180

Williams, S. L. (1987). Competition between the seagrasses Thalassia testudinum and Syringodium filiforme in a Caribbean lagoon. Mar. Ecol. Prog. Ser. 35: 91-98

Williams, S. L. (1988). Disturbance and recovery of a deep- water Caribbean seagrass bed. Mar Ecol. Prog. Ser. 42: $63-71$

Wium-Andersen, S., Borum, J. (1984). Biomass variations and autotrophic production of an epiphyte-macrophyte community in a coastal Danish area. 1. Eelgrass (Zostera marina L.) biomass and net production. Ophelia 23: 33-46 Wyer, D. W., Boorman, L. A., Waters, R. (1977). Studies on the distribution of Zostera in the outer Thames estuary. Aquaculture 12: 215-227

Zieman, J. C. (1982). The ecology of seagrasses of South Florida: a community profile. U. S. Fish Wildl. Serv., Biol. Serv. Program FWS/OBS-82/25, $124 \mathrm{pp}$.

This article was submitted to the editor; it was accepted for printing on October 21,1988 